\title{
Metal Sorption By SEdiments From A MANgrove Reforestation AREa In GuANabara BAy (SE BRAZIL) REVEALED By USING RADIOTRACERS
}

\section{KATIA NORIKO SUZUKI ${ }^{1 *}$, MELISSA NOGUEIRA SONDERMANN ${ }^{1}$, EDIMAR CARVALHO MACHADO ${ }^{2}$, WILSON MACHADO $^{1}$, ALFREDO VICTOR BERNEDO BELLIDO ${ }^{1}$, LUIS FERNANDO BELLIDO ${ }^{3}$ AND RICARDO TADEU LOPES $^{4}$}

\author{
1 Programa de Pós-Graduação em Geoquímica, Universidade Federal Fluminense, CEP 24020-150, Niterói, Rio de Janeiro, Brazil. ksuzuki@id.uff.br; \\ melissa.sonder@gmail.com; wmachado@geoq.uff.br; alfredobellido@gmail.com \\ 2 Instituto Federal de Educação, Ciência e Tecnologia do Rio de Janeiro, CEP 26530-060, Nilópolis, RJ. edimar_machado@yahoo.com.br \\ 3 Instituto de Radioproteção e Dosimetria/ CNEN, CEP 22783-127, Rio de Janeiro, Brazil.. lbellido@cnen.gov.br \\ 4 Laboratório de Instrumentação Nuclear, Universidade Federal do Rio de Janeiro, CEP 21945-970, Rio de Janeiro, Brazil. ricardo@lin.ufrj.br
}

*CORRESPONDING AUTHOR, ksuzuki@id.uff.br

Received on 20 May 2016

Received in revised form on 30 June 2016

Accepted on 5 July 2016

Editor:

Maria Virginia Alves Martins, Universidade do Estado do Rio de Janeiro,

Brazil

\section{Abstract}

This work applied the radiotracer technique to evaluate the chromium (Cr) sorption by sediments of a mangrove degraded area under reforestation phase. The radiotracer ${ }^{51} \mathrm{Cr}(\mathrm{III})$ was used to assess the removal kinetics of this metal from tidal water by underlying sediments in two different environments from the mangrove area of the reserve Parque Natural Municipal Barão de Mauá (Rio de Janeiro, SE Brazil). The results indicated a faster $\mathrm{Cr}(\mathrm{III})$ removal by sediments from the area with initial mangrove reforestation $\left(t_{1 / 2}=12.1 \pm 0.1 \mathrm{~h}\right)$ than estimated for the area with older mangrove reforestation $\left(t_{1 / 2}=18.0 \pm 0.2 \mathrm{~h}\right)$. However, this

\section{Introduction}

Mangrove ecosystems play important roles in tropical coastal areas, since they affect water quality by retaining and stabilizing the sediments and by removing and storing metal contaminants (Lacerda, 2002; Machado et al., 2002). Although this role as biogeochemical barriers for trace metals is recognized in the literature, natural processes and anthropogenic influences (e.g., due to spatial and temporal changes in redox conditions in the sediments) can induce changes in the efficient retention of these elements (Clark et
Citation:

Suzuki, K.N., Sondermann, N.N., Machado, E.C., Machado, W., Bellido, A.V.B., Bellido, L.F., Lopes, R.T., 2016. Metal sorption by sediments from a mangrove reforestation area in Guanabara Bay (SE Brazil) revealed by using radiotracers. Journal of Sedimentary Environments, 1(3): 292-296.

difference was explained by a stronger sediment bioturbation in the area that presented faster $\mathrm{Cr}$ removal (the initial mangrove reforestation zone). These results evidence the importance of the influence of biological activity in the capacity of the mangrove sediment to remove $\mathrm{Cr}(\mathrm{III})$ from tidal waters.

Keywords: Radiotracer. Microcosms. Mangrove. Reforestation. Sorption kinetics.

al., 1998; Marchand et al., 2012), often resulting in metal remobilization (Harbison, 1986; Machado et al., 2008).

The comprehension on trace metal behaviour in different sedimentary environments is important for the implementation of measures to prevent deleterious effects of these potentially toxic elements, improving the management of contaminated areas. This study aims to evaluate the sorption of $\mathrm{Cr}$ (III) from tidal water by underlying mangrove sediments employing a radiotracer technique, in order to 
contribute to the knowledge of the $\mathrm{Cr}$ behaviour in complex mangrove environments. The use of this technique in microcosm experiments have allowed the assessment of mechanisms, kinetics and/or possible reversibility of trace metal transfer across the water-sediment interface of a large variety of aquatic systems. For instance, these studies have included radiotracer experiments on estuarine sediments

\section{Material and methods}

The study sites are located in the northwestern margin of Guanabara Bay (Fig. 1), within a red mangrove (Rhizophora mangle L.) reforestation area in "Parque Natural Municipal Barão de Mauá" (Magé City, Rio de Janeiro State). Sampling stations were established in an initial reforestation (station A; $22^{\circ} 43^{\prime} 14.6^{\prime \prime} \mathrm{S}, 43^{\circ} 11^{\prime} 35.2^{\prime \prime} \mathrm{W}$ ) area and in an older mangrove reforestation (station B; $22^{\circ} 43^{\prime} 16.8^{\prime \prime}$ S, 431'24.8” W) area.

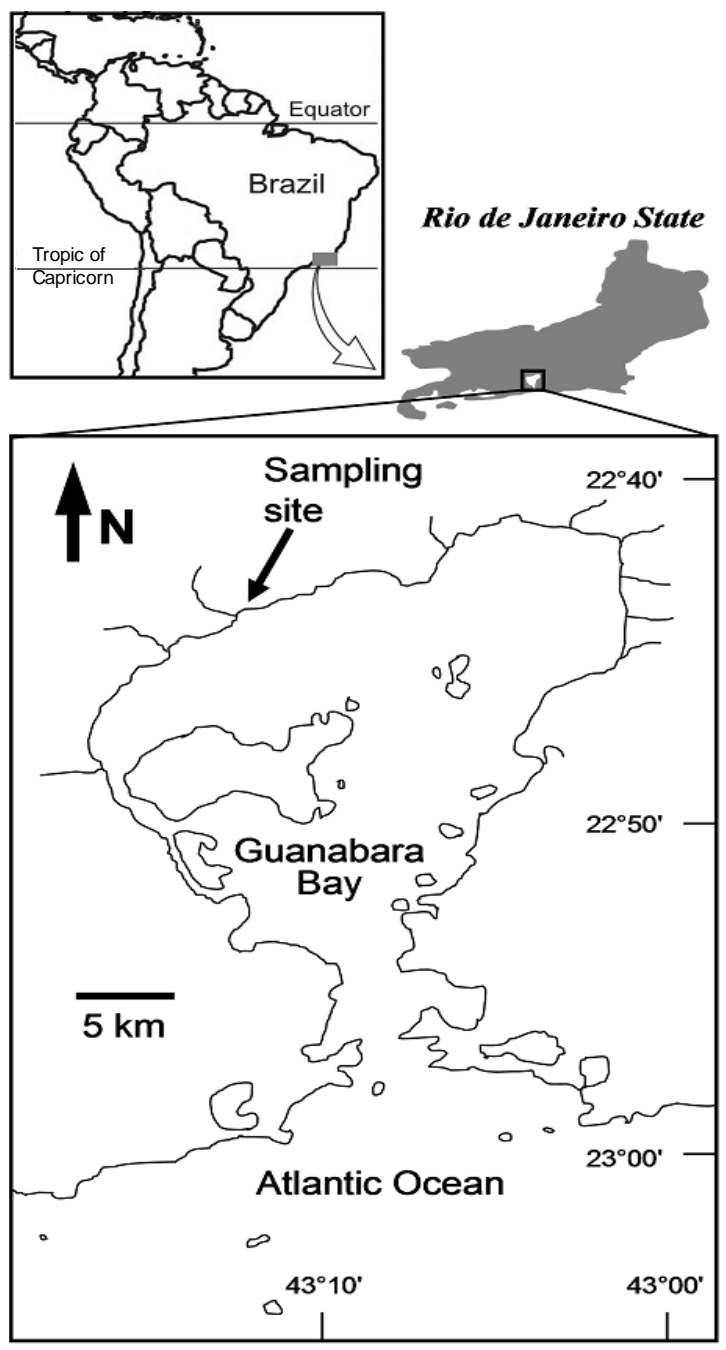

Fig. 1. Sample location area at Guanabara Bay/RJ.
(Petersen et al., 1998; Barros et al., 2004), unvegetated tidal flats (Cournane et al., 2010) and mangrove wetlands (Suzuki et. al, 2015). However, previous studies did not investigate radiotracers removal from tidal waters by sediments of mangrove degraded areas under recuperation activities. Therefore, this work studied an area of mangrove reforestation in Guanabara Bay, Brazil.

Tidal water was sampled from a channel constructed for irrigating the mangrove cultivation area, using a 5-liter plastic container, during the flooding period. Eight short sediment cores (with nearly $6 \mathrm{~cm}$ length) were collected using Plexiglas tubes ( $4.4 \mathrm{~cm}$ diameter, $25 \mathrm{~cm}$ length). In Fig. 2 a schematic view of the experimental apparatus is shown.

The samples were immediately transported to the laboratory, maintaining a tidal water column of $\sim 5 \mathrm{~cm}$ overlying the cores. In the Laboratory of Nuclear Chemistry and Radiochemistry (Universidade Federal Fluminense), the water columns that overlaid the sediments during transport were substituted by a $10-\mathrm{cm}$ tidal water column (corresponding to $150 \mathrm{~mL}$ ) spiked with the radiotracer ${ }^{51} \mathrm{Cr}(\mathrm{III})$ supplied by "Instituto de Pesquisas Energéticas e Nucleares" (IPEN-CNEN/SP; Institute of Energy and Nuclear Research), with an initial activity of $250 \mathrm{~Bq} / \mathrm{mL}$. Since water that floods the sampled mangrove system is oxygenated (Ovalle et al., 1990), oxygenation of the water columns was maintained during the experiments by moist air pumping (Petersen et al., 1998), simulating 6-hours of flooding period.

Water sampling was carried out periodically along 44 hours. Gamma-ray spectrometry with a high-purity $\mathrm{Ge}$ detector (ORTEC-HPGe) was used for determining ${ }^{51} \mathrm{Cr}$ in these water samples.

\section{Results and Discussions}

The temporal variability of $\mathrm{Cr}$ (III) activities from the two study areas are compared in Fig. 3. Faster initial removal rates, followed by slower sorption kinetics, are typically observed in previous studies on radiotracer exchanges across the water-sediment interface (e.g., Petersen et al., 1998; Barros et al., 2004; Suzuki et al., 2012), as it was found in all performed experiments.

However, clear differences were observed among the removal kinetics of $\mathrm{Cr}$ (III) by sediments from the analyzed sites in this work. In station $\mathrm{B}, \mathrm{Cr}(\mathrm{III})$ was removed approximately two times faster than in station $\mathrm{A}$ at the first hour of experiments. On the other hand, station A presented a faster radiochromium removal from water during the following initial hours of experiments. 
These results were a consequence of the shift in the removal kinetics observed at the second hour, only in station B. After this shift, all the relative values of removal were higher in station $\mathrm{B}$ than those determined in station $\mathrm{A}$. More than $50 \%$ of the initial activities of $\mathrm{Cr}$ (III) in water were removed within 24 hours, but station $\mathrm{B}$ displayed a higher removal capacity than station A ( $\sim 60 \%$ vs. $90 \%$ removals). The Cr(III) sorption by sediments of station A was stabilized at 24 hours, whereas this stabilization was not found in sediments of station $\mathrm{B}$, which maintained a slow removal trend until 44 hours.

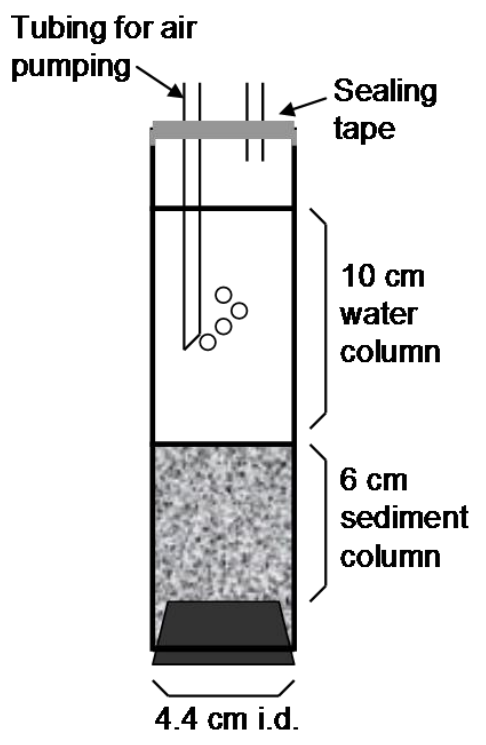

Fig. 2. Experimental apparatus employed (adapted from Petersen et al., 1998).

The general shapes of the sorption curves followed a first order removal trend (Fig. 3). Therefore, first-order constants of the removal velocity $(\mathrm{k})$ and half-removal times $\left(\mathrm{T}_{1 / 2}\right)$ were estimated for these experiments (Table 1). The most efficient sorption of the sediments of station $\mathrm{A}$ is indicated by higher $\mathrm{k}$ value and smaller $\mathrm{T}_{1 / 2}$ value.

The importance of mangrove vegetation contribution to the establishment of favourable conditions for the retention of metals by sediments is well characterized in the literature and this capacity is due to physical stabilization, organic matter accumulation and development of physical and chemical conditions that constitute a biogeochemical barrier for these elements (Lacerda, 2002; Suzuki et al., 2015).

The variability in these factors between stations may contribute to explain the contrasts observed in the studied stations. An intense development of polychaete burrows was observed in the upper layers of sediment cores from station A (Fig. 4), but this biological disturbance was not found in sediments from station $B$. The burrowing activity of benthic fauna is well recognized as an important factor that improves the ability of sediments to remove radiotracers from the overlying water (Santschi et al., 1984; Osaki et al., 1997; Suzuki et al., 2012). This factor was the most probable explanation for the differences in $\mathrm{Cr}(\mathrm{III})$ sorption kinetics between stations $\mathrm{A}$ and $\mathrm{B}$ in the study area.

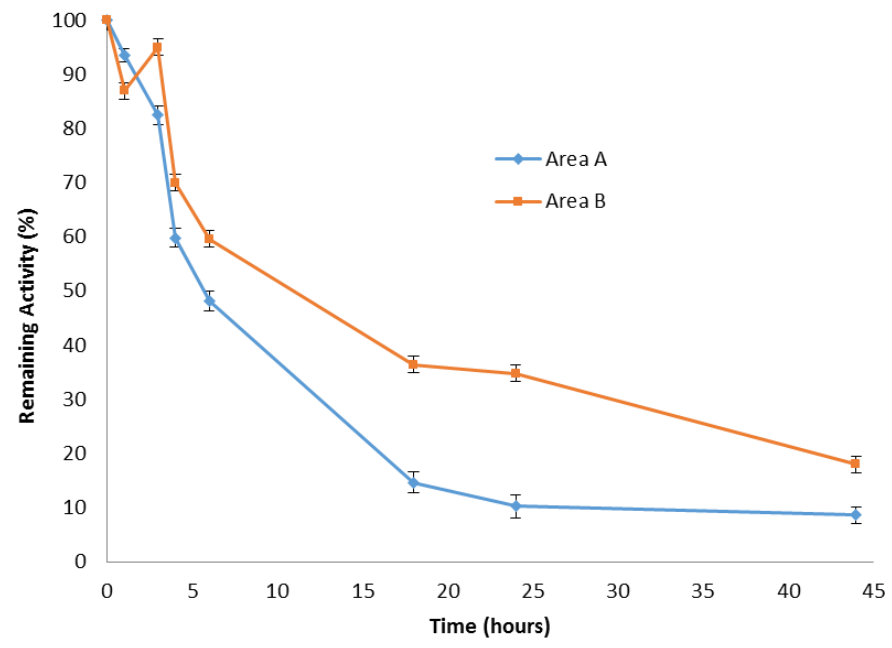

Fig. 3. Percent remaining activities of ${ }^{51} \mathrm{Cr}$ in relation to initial activities in the cores of mangrove reforestation (weighted average, $\mathrm{n}=4)$.

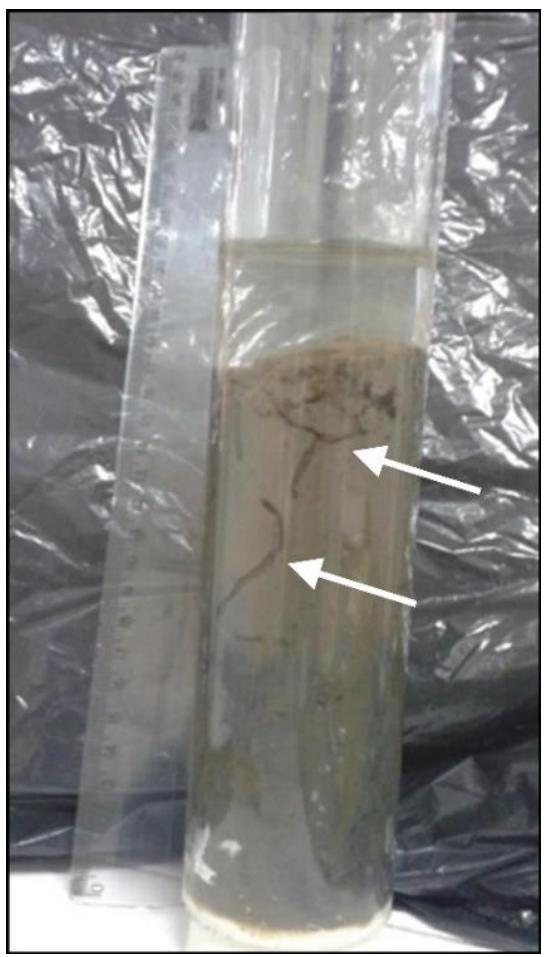

Fig. 4. Sediment core sampled from station A, with welldeveloped bioturbation zones (burrows are indicated by arrows). 
Tab. 1: Values resulting from sorption kinetics of areas A and B

\begin{tabular}{lcccccc}
\hline Kinetics 44hs & $\mathbf{k}$ & Error & $\mathbf{R}^{\mathbf{2}}$ & $\mathbf{S D}$ & $\mathbf{T}_{\mathbf{1} 2 \mathbf{2}} \mathbf{( h \mathbf { h } )}$ & Error \\
\hline Area A & 0.0575 & 0.0004 & 0.8886 & 20.9532 & 12.1 & 0.1 \\
Area B & 0.0385 & 0.0004 & 0.9472 & 9.5460 & 18.0 & 0.2 \\
\hline
\end{tabular}

\section{Conclusion}

The use of the radiotracer ${ }^{51} \mathrm{Cr}(\mathrm{III})$ allowed the evaluation of removal constants and the respective half-removal times of $\mathrm{Cr}(\mathrm{III})$ from the tidal water underlying the mangrove sediments.

A faster radiotracer sorption by sediments was observed for the area with initial mangrove reforestation in comparison with an older mangrove reforestation zone $\left(\mathrm{t}_{1 / 2}\right.$ $=12.1 \pm 0.1 \mathrm{~h}$ vs. $18.0 \pm 0.2 \mathrm{~h})$. The differences between sites were probably due to stronger sediment bioturbation observed in the area with mangrove plant cover that presented faster $\mathrm{Cr}$ removal. These results evidenced and confirmed previous studies on the large importance of bioturbation influence in the capacity of mangrove sediments to remove $\mathrm{Cr}(\mathrm{III})$ from tidal waters.

\section{Acknowledgments}

The authors would like to thank Dr. J.A. Osso Jr. (IPENCNEN/SP) for providing the radiotracer and Dr. Anderson C. Borges for helping in the field work. Rio de Janeiro State Research Foundation (FAPERJ) provided financial support (Project No. E26/112.072/2012).

K.N. Suzuki would like to thank Brazilian Ministry of Education (CAPES) for her post-doctoral grant.

\section{References}

Barros, H., Laissaoui, A., Abril, J. M., 2004. Trends of radionuclide sorption by estuarine sediments. Experimental studies using ${ }^{133} \mathrm{Ba}$ as a tracer. Science of the Total Environment 319, $253-$ 267. doi:10.1016/S0048-9697(03)00408-X.

Clark, M. W., McConchie, D. M., Lewis, D. W., Saenger, P., 1998. Redox stratification and heavy metal partitioning in Avicenniadominated mangrove sediments: a geochemical model. Chemical Geology 149, 147 - 171. doi.org/10.1016/S00092541(98)00034-5.

Cournane, S., Vintró, L. L., Mitchell, P. I., 2010. Modelling the reworking effects of bioturbation on the incorporation of radionuclides into the sediment column: implications for the fate of particle-reactive radionuclides in Irish Sea sediments. Journal of Environmental Radioactivity 101, 985 - 991. doi: 10.1016/j.jenvrad.2010.07.006.

Harbison, P., 1986. Mangrove muds - A sink and source for trace metals. Marine Pollution Bulletin 17, 273 - 276. doi:10.1016/0025-326X(86)90057-3.

Lacerda, L.D., 2002. Mangrove Ecosystems: Function and Management. Heidelberg: Springer Verlag. 292p.

Machado, E. C., Machado, W., Bellido, L. F., Patchineelam, S. R., Bellido, A. V. B., 2008. Removal of Zinc from Tidal Water by Sediments of a Mangrove Ecosystem: A Radiotracer Study. Water, Air, \& Soil Pollution 192, 77 - 83. doi: 10.1007/s11270008-9636-9

Machado, W., Moscatelli, M., Rezende, L.G., Lacerda, L.D., 2002. Mercury, zinc, and copper accumulation in mangrove sediments surrounding a large landfill in southeast Brazil. Environmental Pollution 120, 455 - 461. doi:10.1016/S02697491(02)00108-2.

Marchand, C., Fernandez, J.-M., Moreton, B., Landi, L., LallierVergès, E., Baltzer, F., 2012. The partitioning of transitional metals (Fe, Mn, Ni, Cr) in mangrove sediments downstream of a ferralitized ultramafic watershed (New Caledonia). Chemical $\begin{array}{llll}\text { Geology } & 300 / 301, & 70 \quad & -\end{array}$ doi:10.1016/j.chemgeo.2012.01.018.

Osaki, S., Sugihara, S., Momoshima, N., Maeda, Y., 1997. Biodiffusion of ${ }^{7} \mathrm{Be}$ and ${ }^{210} \mathrm{~Pb}$ in intertidal estuarine sediments. Journal of Environmental Radioactivity 37, 55 - 71 . doi:10.1016/S0265-931X(96)00079-3.

Ovalle, A.R.C., Rezende, C.E., Lacerda, L.D., Silva, C.A.R., 1990. Factors affecting the hydrochemistry of a mangrove tidal creek, Sepetiba Bay, Brazil. Estuarine, Coastal and Shelf Science 31, 639 - 650. doi:10.1016/0272-7714(90)90017-L.

Petersen K., Kristensen E., Bjerregaard P., 1998. Influence of bioturbating animals on flux of cadmium into estuarine sediments. Marine Environmental Research 45, 403 - 415. doi:10.1016/S0141-1136(98)00102-0.

Santschi, P. H., Nyffeler, U. P., O’Hara, P., Buchholtz, M., Broecker, W. S.,1984. Radiotracer uptake on the sea floor: results from the MANOP chamber deployments in the eastern 
Pacific. Deep Sea Research 31, 451 - 468. doi:10.1016/01980149(84)90096-7.

Suzuki, K.N., Machado, E.C., Machado W., Bellido, L.F., Bellido, A.V.B., Lopes, R.T., 2015. Radiotracers as a tool to elucidate trace element behaviour in the water-sediment interface. In: Walther, C.; Gupta, D.K. (eds). Radionuclides in the Environment - Influence of chemical speciation and plant uptake on radionuclide migration. Springer International Publishing, pp. 101-113.

Suzuki K.N., Machado E.C., Machado W., Bellido A.V.B., Bellido L.F., Osso J.A. Jr, Lopes R.T., 2012. Selenium, chromium and cobalt diffusion into Mangrove sediments: radiotracer experiment evidence of coupled effects of bioturbation and rhizosphere. Water, Air, \& Soil Pollution 223, 3887 - 3892. doi: 10.1007/s11270-012-1157 